\title{
Strength Assessment of Concrete Cubes Containing Variable Mixtures of Portland Cement and Granite Dust of the Maddhapara Mine, NW Bangladesh
}

\author{
Md. Rafiqul Islam ${ }^{1, ~ *, ~ M a r z i a ~ M o h s i n " ~}{ }^{1}$, Mir Md. Abdul Hannan², Mohammed Omar Faruque ${ }^{1}$, \\ Md. Kamrul Islam ${ }^{3}$, Md. Abdur Rahman ${ }^{4}$, Md. Ahasan Habib Shahin ${ }^{2}$ \\ ${ }^{1}$ Department of Petroleum \& Mining Engineering, Shahjalal University of Science \& Technology, Sylhet, Bangladesh \\ ${ }^{2}$ Maddhapara Granite Mining Company Limited, Maddhapara, Parbatipur, Dinajpur, Bangladesh \\ ${ }^{3}$ Department of Petroleum \& Mining Engineering, Jessore University of Science \& Technology (JUST), Jessore, Bangladesh \\ ${ }^{4}$ Department of Geology and Mining, University of Rajshahi, Rajshahi, Bangladesh
}

Email address:

dmrislam@gmail.com (M. R. Islam)

${ }^{*}$ Corresponding author

\section{To cite this article:}

Md. Rafiqul Islam, Marzia Mohsin, Mir Md. Abdul Hannan, Mohammed Omar Faruque, Md. Kamrul Islam, Md. Abdur Rahman, Md. Ahasan Habib Shahin. Strength Assessment of Concrete Cubes Containing Variable Mixtures of Portland Cement and Granite Dust of the Maddhapara Mine, NW Bangladesh. American Journal of Civil Engineering. Vol. 4, No. 6, 2016, pp. 319-325. doi: 10.11648/j.ajce.20160406.18

Received: September 11, 2016; Accepted: September 21, 2016; Published: October 18, 2016

\begin{abstract}
Granite dust is a waste material which is produced during crushing and grinding process of granite stone. The annual production rate of the Maddhapara Granite Mine is 1.65 million metric tons from the underground mine. It has been estimated that the average weight of the granite dust is about $10 \%$ of the total weight of the annually produced granite rock from the Maddhapara Mine. The granite dust in Bangladesh is negligible in construction works, although it has a huge potential for the replacement of natural fine aggregates. The granite dust of Maddhapara Mine may be an alternative to natural sand for construction works. The present research highlights the compressive strength behavior of concrete cubes containing granite dust as a fine aggregate associated with variable mixtures of Portland cement. The three stages of working methods have been applied in the present research work, like- (i) collection of samples from the field, (ii) grain size analysis, and (iii) compressive strength test of concrete cubes with different curing periods of 7, 14 and 28 days. Compressive strength test was carried out on five concrete cubes with grades of M5, M10, M15, M20, M25. The grain size distribution curve as well as $\mathrm{C}_{\mathrm{u}}(9.88)$ and $\mathrm{C}_{\mathrm{c}}(0.671)$ values reveal that the Maddhapara granite dust is classified as well graded sand that can be enhanced high compressibility and shear strength. The compressive strength values of 14 and 28 days curing periods reveal that the M15 grade is a good quality option because of its high compressive strength associated with reasonable amount of cement and granite dust ratio. From the technical points of view, it can be focused that the Maddhapara granite dust can be used in various purposes. Appropriate utilization of granite dust would not only save the large amount of construction cost, but also would open a new window for the economic sector of the mine.
\end{abstract}

Keywords: Granite Dust, Grain Size Curve, Concrete Cube, Compressive Strength, Maddhapara Granite Mine, Bangladesh

\section{Introduction}

Concrete is a widely used construction substance which is consisting of cementing material, fine aggregate, coarse aggregate and required quantity of water. The fine aggregate is usually natural sand. Properties of fine aggregate affect the durability and performance of concrete. So, fine aggregate is an essential component of concrete. The most commonly used fine aggregate is natural river or pit sand. Fine and coarse aggregate constitute about $75 \%$ of total volume of the concrete. It is, therefore, important to obtain right type and good quality aggregate, because the aggregate form the main matrix of concrete $[1,2]$. Granite dust is a waste material that produced from granite stone industry in the form of non-biodegradable fine powder during cutting and grinding process of granite 
stone. Granite grains and dust are considered waste materials during production of granite products. These processes produce a large amount of waste materials. It has a huge potential of granite dust as a replacement of natural fine aggregates [3, 4].

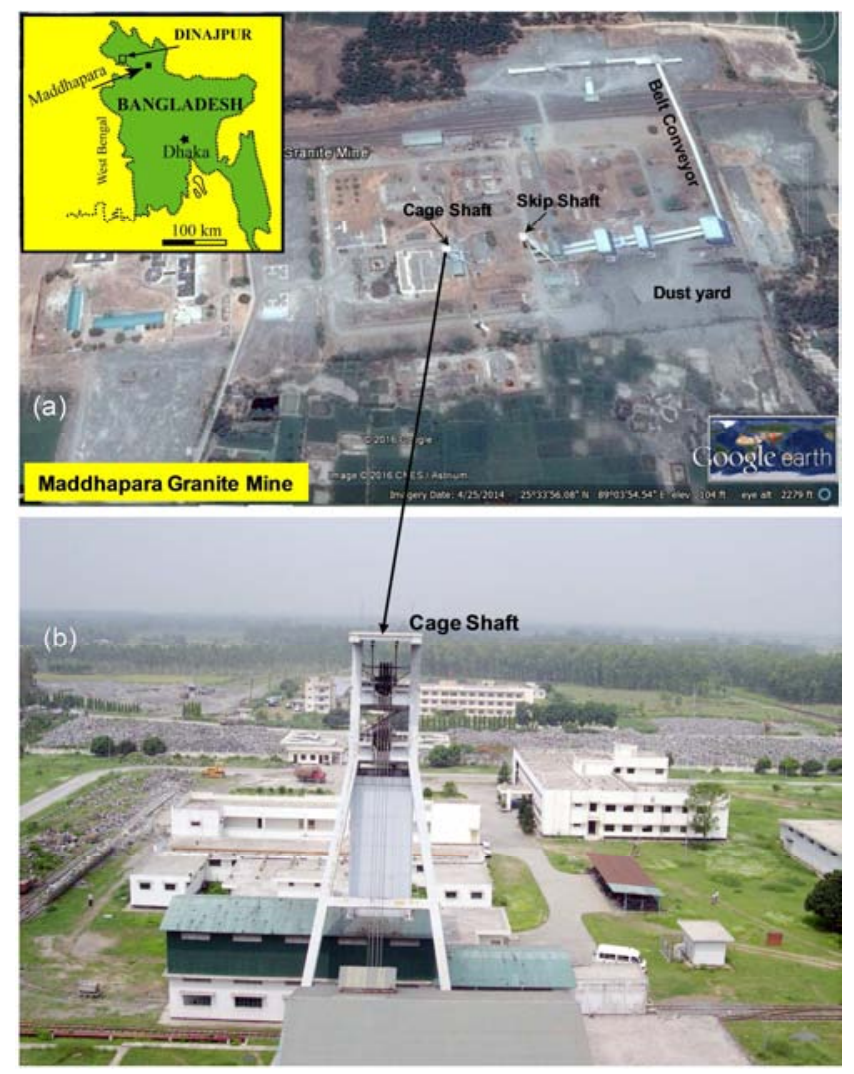

Figure 1. (a) Location, and (b) Birdseye view of the Maddhapara Granite Mine, Northwest Bangladesh.

Fine aggregates may frequently contain deleterious substances that are considered harmful to concrete. One type of deleterious materials is the particles finer than $75 \mu$ sieve. Particles size finer than $75 \mu$ may be present in the aggregates in dispersed form, or as lumps or as coatings. In fine aggregates, these materials are commonly in the dispersed form and their composition may be clay, silt or stone dust. Clays and silts are commonly present in natural sand and stone dust is present in crushed sand [5, 6]. The presence of very fine materials in excessive quantities influences the performance and properties of fresh and hardened concrete [7, $8,9]$. Literatures review reveal that granite dust had a positive effect on producing concrete bricks [10]. A study result reveals that the concrete cubes with stone dust developed about $17 \%$ higher strength in compression, $7 \%$ more split tensile strength and $20 \%$ more flexural strength than the concrete cubes with river sand as fine aggregate [11]. Reinforced concrete beams with crusher dust sustained about $6 \%$ more load under two point loading and developed smaller deflections and smaller strains than the beams with river sand [12]. During the industrial process, the granite grains get mixed with water and form a colloidal waste. When the slurry is deposited, its water content is severely reduced due to factors like evaporation and the waste becomes a dry mound consisting of non-biodegradable granite dust [4].

In 1974, a large reserve of Precambrian Basement Complex (BC) rock especially granite rock was discovered in the subsurface of the Maddhapara area by the Geological Survey of Bangladesh (GSB). The Maddhapara Granite Mine is the first underground hard rock mine of the country with an annual production of 1.65 million metric tons. The mine is located in Maddhapara area of Dinajpur district of northwest Bangladesh (Figure 1). In accordance with the public demand, the produced granite rock is being crushed into five categories, like- (i) greater than $250 \mathrm{~mm}$ (boulder), (ii) $60-80 \mathrm{~mm}$, (iii) 40-60 mm, (iv) $20-40 \mathrm{~mm}$, (v) 5-20 mm, and finally, dust (0-5 $\mathrm{mm}$ ), which is actually the byproduct (Figure 2). According to the official statement, it is estimated that the minimum and maximum weight of granite dust is ranged from $7 \%$ to $13 \%$ of the original weight of granite rock. It is rational to reveal that the use of granite dust in Bangladesh is negligible in construction works. Due to rapid growth in construction activity, the available sources of natural sand are going to be ended in Bangladesh. Moreover, good quality of sand may have to be transported from long distance to the construction site that adds supplementary construction costs. In some cases, natural sand may not be of good quality. Hence, if the strength of granite dust is proved adequately, its use in construction works would provide another avenue for economical use of granite dust. Therefore, granite dust of Maddhapara mine may be an alternative to natural sand for construction works. For the case of economic utilization of granite dust, it is essential to understand the strength characteristics of concrete cubes or cylinders that consist of granite dust and Portland cement, where partial replacement of the coarse aggregate would be negligible. In the present study, granite dust was chosen as a fine aggregate and Portland cement was added to the mixture that can be acted as a binding agent. The present study highlights the strength behavior of concrete cubes containing granite dust as a fine aggregate associated with variable mixtures of Portland cement. Three major objectives of the present study are to-

- determine the grain size analysis of granite dust

- assess the compressive strength of concrete cubes with various ratio of Portland cement and granite dust as fine aggregate, and

- investigate the uses and economic feasibility of granite dust.

\section{An Overview of the Proportion of Cement Mixtures in Concrete}

The various types of concrete and their respective ratios and nature of work are shown in Table-1. The proportion of concrete mixes are shown in table 1, where the fine aggregate is mostly sand. The coarse aggregates are usually coarse gravel or large chunks of rocks. In the present study, our aim is to entirely replacement of fine aggregate (sand) with granite dust, where coarse aggregate materials are negligible. The 
compressive strength values of concrete were measured based on the different proportions of Portland cement and granite dust after a curing period of 7,14 and 28 days.

Table 1. Concrete mixes and purposes [13].

\begin{tabular}{|c|c|c|}
\hline $\begin{array}{l}\text { Grades of } \\
\text { concrete }\end{array}$ & $\begin{array}{l}\text { Proportion } \\
\text { (C: FG: CG) }\end{array}$ & Nature of works \\
\hline M5 & $(1: 5): 10$ & $\begin{array}{l}\text { Mass concrete for heavy walls, } \\
\text { foundation and footings }\end{array}$ \\
\hline M10 & $(1: 3): 6$ & $\begin{array}{l}\text { Mass concrete and foundations of less } \\
\text { importance }\end{array}$ \\
\hline M15 & $(1: 2): 4$ & $\begin{array}{l}\text { For general RCC works (slab, beams, } \\
\text { columns etc.) }\end{array}$ \\
\hline M20 & $(1: 1.5): 3$ & $\begin{array}{l}\text { Water retaining structures, piles and } \\
\text { general } \mathrm{RCC} \text { structure }\end{array}$ \\
\hline M25 & $(1: 1): 2$ & $\begin{array}{l}\text { Heavily loaded RCC structure long span } \\
\text { slab, beams etc. }\end{array}$ \\
\hline
\end{tabular}

Abbreviations: $C=$ Cement, $F G=$ Fine Aggregates, $C G=$ Coarse aggregate. In the present study, we used the ratio that has been marked within brackets of Table 1.

\section{Methodology}

The present study includes three stages of working procedure, like- (i) collection of samples from the field, (ii) grain size analysis; and finally (iii) compressive strength test of cubic samples.
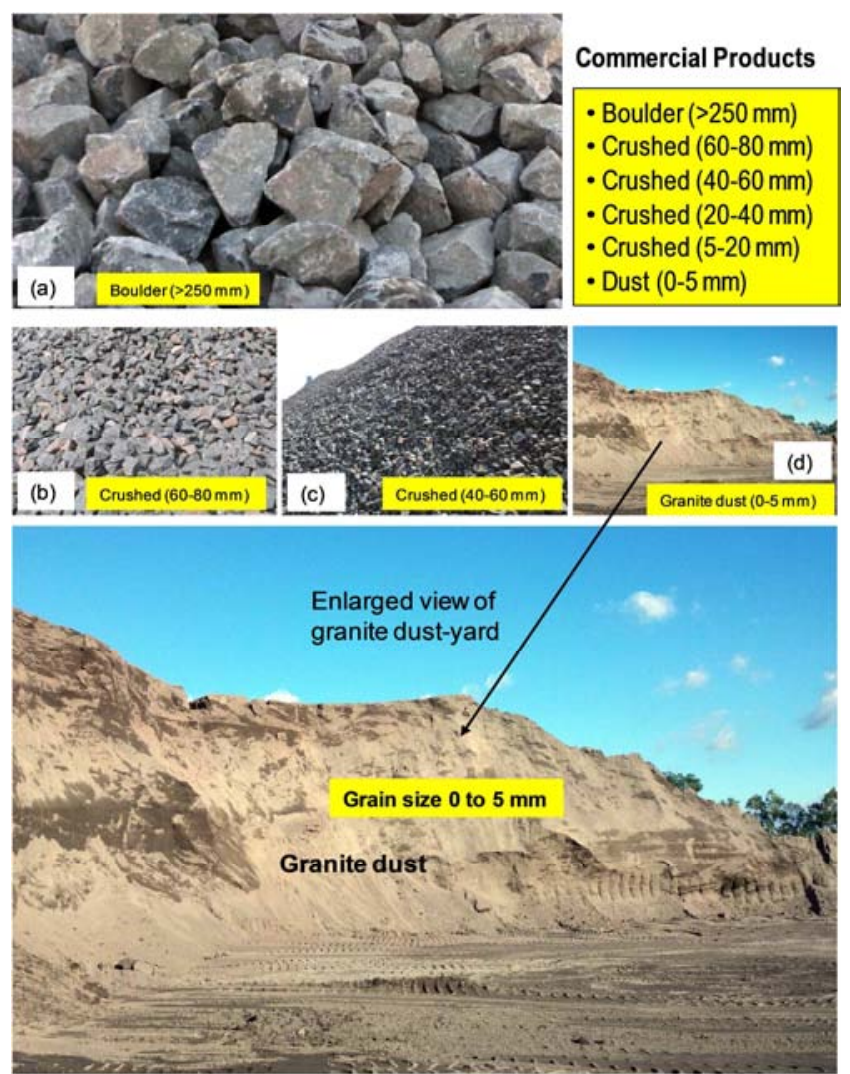

Figure 2. Some examples of commercial products (a-d) of the Maddhapara Granite Mine, Bangladesh (please see the dust-yard location in Figure 1)

\subsection{Sample Collection and Grain Size Analysis}

20 kilograms of granite dust was collected from the dust-yard (Figures 1 and 2) of the Maddhapara Granite Mine area. The collected samples were dried in the air and sunlight first and then the sieve analysis was carried out to determine the percentage $(\%)$ of different grain sizes contained within the sample. Grain size analysis provides the grain size distribution curve, which is required in classifying the ingredients. The distribution of different grain sizes affects the engineering properties of concrete.

\subsection{Compressive Strength Test}

The compressive strength test was carried out on concrete cubes of grades M5, M10, M15, M20, M25 after a curing period of 7, 14 and 28 days.

\subsubsection{Mixture and Ratio Calculation of Portland Cement and Granite Dust for Concrete}

We prepared 15 cubes for the experiment.

Calculation for the M5 grade: The total volume of mixtures to make three cubes were calculated by using the following techniques-

Volume $_{\text {cube }}=3[2$ in $\times 2$ in $\times 2$ in $]=3 \times 8=24$ in $^{3}$

$$
=24 \operatorname{in}^{3}\left(\frac{1 f t^{3}}{(12 i n)^{3}}\right)=0.0138 f t^{3}
$$

Then we converted the volume into an equivalent weight of mixture as follows-

$$
\begin{aligned}
& \text { Weight }=0.0138 \mathrm{ft}^{3}\left(\frac{150 \mathrm{lb}}{\mathrm{ft}}\right)=2.083 \mathrm{lb} \\
& =2.083 \mathrm{lb}\left(\frac{0.45 \mathrm{~kg}}{\mathrm{lb}}\right)=0.9375 \mathrm{~kg}
\end{aligned}
$$

For 1:5 mixture, the weight of cement required is

Weight $_{\text {cement }}=\left(\frac{1}{6}\right) \times 0.9375=0.15625 \mathrm{~kg}$

Weight granite dust $=\left(\frac{5}{6}\right) \times 0.9375=0.78125 \mathrm{~kg}$

Then we determined the amount of water.

- The weight of water is specified by the w/c ratio.

- For this experiment, the $\mathrm{w} / \mathrm{c}=0.485$

- For the mixture, the weight of cement is $0.15625 \mathrm{~kg}$. Therefore, the weight of water required is:

- Weight $_{\text {water }}=0.15625 \mathrm{~kg} \times(0.485)=0.7578 \mathrm{~kg}$

Following the similar technique, we calculated the required weight for different grades of M10, M15, M20, M25.

\subsubsection{Preparation of Concrete Cubes for Compressive Strength Test}

- At first we mixed Portland cement and granite dust in dry condition according to the measured weight with a trowel for 1 minute.

- Then we added water and kept mixing until the mixture was of uniform color.

- Immediately after mixing, we placed the mixture in the cube with a dimension of 2 in $\times 2$ in $\times 2$ in (Figure $3 a$ ).

- First we placed a layer of mixture about 1 inch $(25 \mathrm{~mm})$ (approximately one half of the depth of the mould) in all of the cube compartments.

- Then we tamped the mixture in each cube compartment 32 times in about 10 seconds in 4 rounds, where each round to be at right angles to the other and consisting of 
eight adjoining strokes over the surface of the specimen, as illustrated in Figure $3 b$.

- When the tamping of the first layer in all of the cube compartments was completed, the compartments were filled with the remaining mixture and then tamped again as specified for the first layer.

- After the completion of the tamping, the tops of all cubes were extend slightly above the tops of the moulds with more mixtures and a trowel was used to smooth off the cubes by drawing the flat side of the trowel

- Five sets of cubes were casted for the five different ratios of M5, M10, M15, M20, M25.

- The cube moulds were placed in temperature of $27 \pm 2^{\circ} \mathrm{C}$ and $90 \%$ relative humidity for 24 hours.

- After 24 hours the cubes were removed from the mould and immediately submerged in clean water till testing

\subsubsection{Test Procedures}

- Each cube was wiped to a surface-dry condition and any loose grains from the faces that would be in contact with the bearing blocks of the testing machine were removed. The faces were checked by applying a straight-edge. If there was an appreciable curvature, we grinded the face or faces to plane surfaces or discarded the specimen. A periodic check of the cross-sectional area of the cube mould was made.

- The load was applying to specimen faces that were in contact with the true plane surfaces of the cube. The cube was placed carefully in the testing machine below the centre of the upper bearing block. Prior to the testing of each cube, it is necessary to focus that the spherically seated block was free to tilt. No cushioning or bedding materials were used. The spherically seated block was brought into uniform contact with the surface of the specimen. Load was applied at a relative rate of movement between the upper and lower platens corresponding to a loading on the specimen with the range of 200 to $400 \mathrm{lbs} / \mathrm{s}$ (900 to $1800 \mathrm{~N} / \mathrm{s}$ )[14]. The load was applying until the cube breaks.

\subsubsection{Strength Calculation}

- The total maximum load indicated by the testing machine was recorded, and the compressive strength was calculated accordingly as follows:

$$
F=\frac{P}{A}
$$

where,

$F=$ compressive strength in psi or $[\mathrm{MPa}]$

$P=$ total maximum load in $\mathrm{lbf}$ or $[\mathrm{N}]$, and

$A=$ area of loaded surface $\mathrm{in}^{2}$ or $\left[\mathrm{mm}^{2}\right]$.

- Compressive strength calculation for the M5 grade after 7 days of curing:

Total maximum load from compressive strength machine, $\mathrm{P}$ $=19.4 \mathrm{kN}$

Area of cube specimen, $\mathrm{A}=(2 \mathrm{in})^{2}=(2 \times 25.4)^{2} \mathrm{~mm}^{2}=2580$ $\mathrm{mm}^{2}$
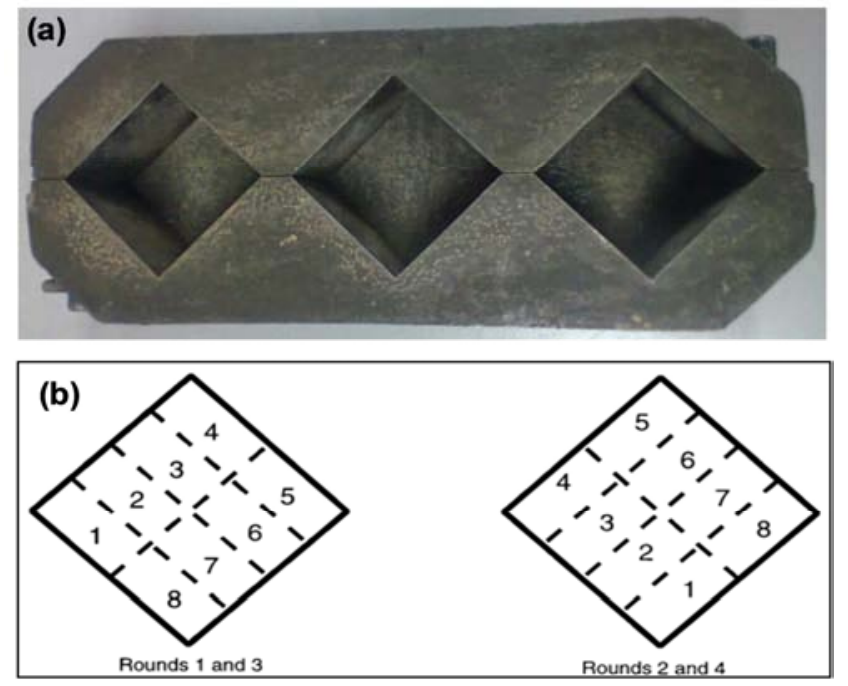

Figure 3. (a) Cube mould of dimension $=(2$ in $\times 2$ in $\times 2$ in $)$, (b) Order of tamping in moulding of test specimens.

Compressive strength, $\mathrm{F}=\frac{19.4 \times 10^{3}}{2580} \mathrm{~N} / \mathrm{mm}^{2}=7.5 \mathrm{MPa}$

The other compressive strength values of grades M5, M10, M15, M20, M25 for curing periods 7, 14 and 28 days were calculated by following the same method.

\section{Rest Results}

\subsection{Grain Size Analysis of Granite Dust}

The grain size analysis of granite dust showed that it is well distributed with grain size of $0.1-5.0 \mathrm{~mm}$ (Figure 4 ). The value of co-efficient of uniformity $\left(\mathrm{C}_{\mathrm{u}}\right)$ is $9.88 . C_{u}$ means it indicates the size range of particle. In the present analysis, the larger value $(9.88)$ of coefficient of uniformity $\left(C_{u}\right)$ means larger size range of particles are remained in granite dust. The value also indicates that the granite dust is not uniform, which is sometimes denoted as a well graded dust particles. For the case of poorly graded condition, the particles all have about the same size. It is rational to mention that the value of co-efficient of uniformity $\left(C_{u}\right)$ is larger than 1 . In the present analysis, the values of $\mathrm{D}_{10}, \mathrm{D}_{30}, \mathrm{D}_{60}$ are as follows-

$$
\begin{aligned}
& \mathrm{D}_{10}=0.167, \\
& \mathrm{D}_{30}=0.430, \\
& \mathrm{D}_{60}=1.65
\end{aligned}
$$

Therefore, the co-efficient of uniformity is, $C_{u}=\frac{D_{60}}{D_{10}}$ $=\frac{1.55}{0.167}=9.88$

The co-efficient of curvature is, $C_{c}=\frac{D_{30}^{2}}{D_{10} \times D_{60}}=\frac{0.407^{2}}{0.167 \times 1.55}$ $=0.671$

\subsection{Compressive Strength Test Results of Concrete Cube Moulds}

\subsubsection{Strength After a Curing Period of 7 Days}

The compressive strength test was carried out on five cubes with grades of M5, M10, M15, M20, M25. After a curing period of 7 days, the test result were $7.5 \mathrm{MPa}, 14.34 \mathrm{MPa}, 17.6$ 
$\mathrm{MPa}, 19.5 \mathrm{MPa}, 19.9 \mathrm{MPa}$, for the grades of M5, M10, M15, and Figure 5.

M20, M25, respectively. The test results are shown in Table 2

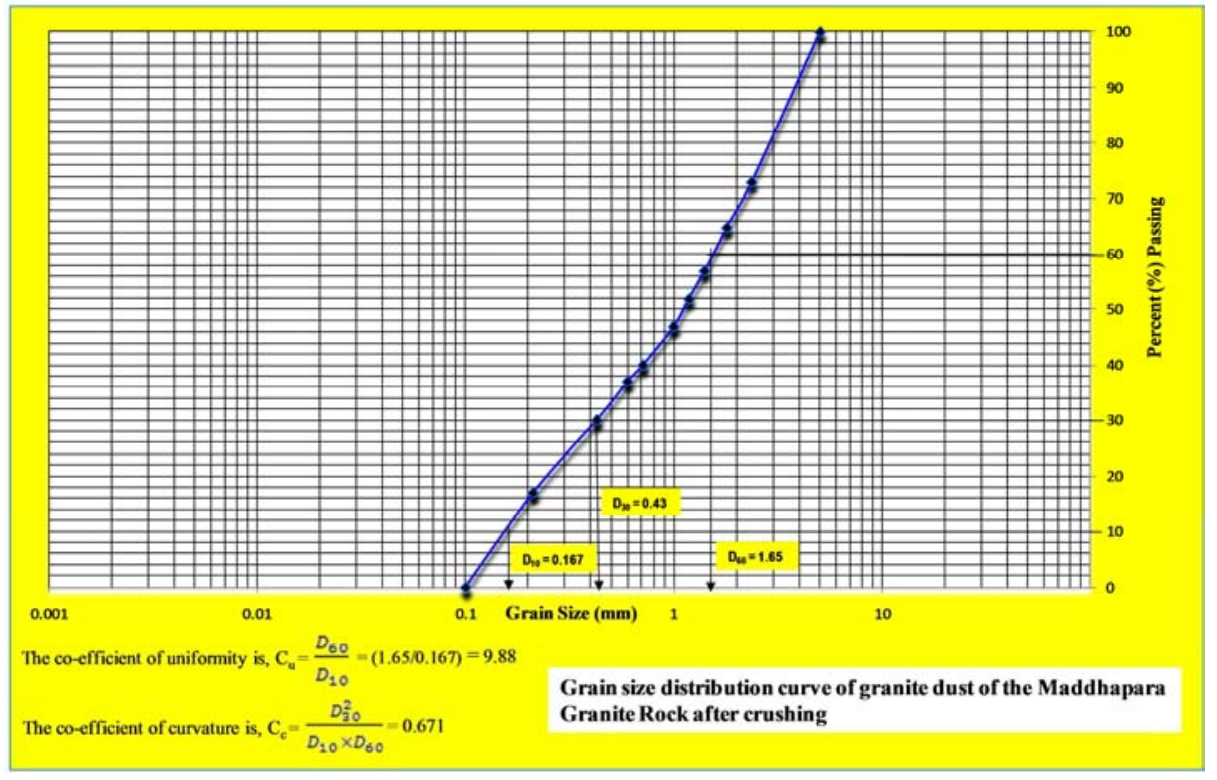

Figure 4. Graphical presentation of grain size analysis data of granite dust of the Maddhapara mine.

\subsubsection{Strength After a Curing Period of 14 Days}

After a curing period of 14 days, compressive strength test was carried out on five cubes with grades of M5, M10, M15, M20, M25. The test results were 9.8 MPa, 12.1 MPa, 23.57 MPa, 20.4 MPa, and 28.2 MPa, for the grades of M5, M10, M15, M20, M25, respectively. The test results are shown in Table 2 and Figure 5.

Table 2. Compressive strength test results after 7, 14 and 28 curing days.

\begin{tabular}{llllllll}
\hline \multirow{2}{*}{ Grade } & \multirow{2}{*}{ Ratio } & \multicolumn{2}{l}{ Strength after 7 days curing period } & \multicolumn{2}{l}{ Strength after 14 days curing period } & \multicolumn{2}{l}{ Strength after 28 days curing period } \\
\cline { 3 - 8 } & & $\begin{array}{l}\text { Maximum } \\
(\boldsymbol{k N})\end{array}$ & $\begin{array}{l}\text { Compressive Strength } \\
(\mathbf{M P a})\end{array}$ & $\begin{array}{l}\text { Maximum } \\
(\boldsymbol{k N})\end{array}$ & $\begin{array}{l}\text { Compressive Strength } \\
(\mathbf{M P a})\end{array}$ & $\begin{array}{l}\text { Maximum Load } \\
(\boldsymbol{k N})\end{array}$ & $\begin{array}{l}\text { Compressive Strength } \\
(\boldsymbol{M P a})\end{array}$ \\
\hline M5 & $1: 5$ & 19.40 & 7.50 & 25.30 & 9.80 & 31.10 & 12.07 \\
M10 & $1: 3$ & 37.00 & 14.34 & 31.20 & 12.10 & 43.08 & 16.70 \\
M15 & $1: 2$ & 45.50 & 17.60 & 60.80 & 23.57 & 71.50 & 27.70 \\
M20 & $1: 1.5$ & 50.20 & 19.50 & 52.60 & 20.40 & 66.80 & 25.90 \\
M25 & $1: 1$ & 51.40 & 19.90 & 72.70 & 28.20 & 84.50 & 32.76 \\
\hline
\end{tabular}
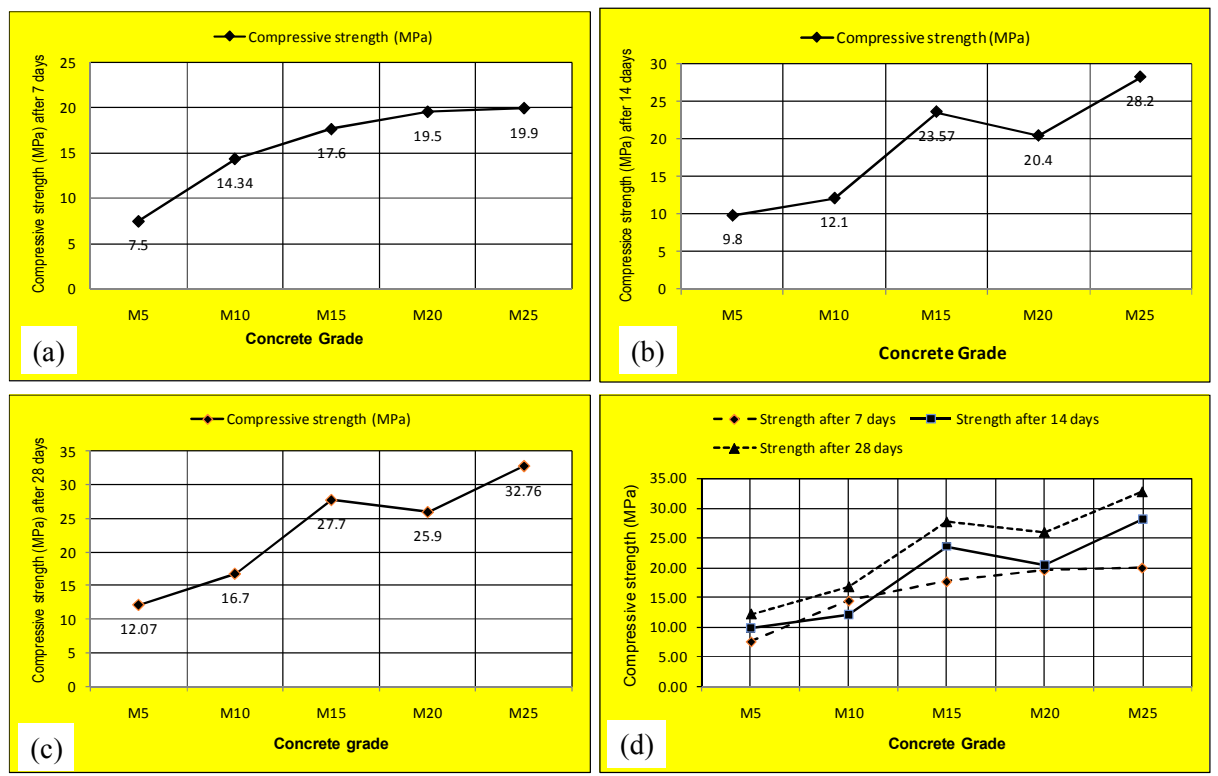

Figure 5. Graphical presentation of compressive strength test data after curing periods of (a) 7 days, (b) 14 days and (c) 28 days (please see details in Table 2).Figure 5 b shows a comparative strength data among 7, 14, and 28 days. 


\subsubsection{Strength After a Curing Period of 28 Days}

After a curing period of 28 days, the compressive strength test values of five cubes with grades of M5, M10, M15, M20, $\mathrm{M} 25$, were 12.7 MPa, 16.7 MPa, 27.7 MPa, 25.9 MPa, and 32.76 MPa, respectively. The test results are shown in Table 2 and Figure 5. The highest strength values are observed for curing periods of 28 days.

\subsubsection{Comparison of Strength Test Results}

A comparative strength test values with different grades of M5, M10, M15, M20, M25 associated with curing periods of 7, 14 and 28 days are shown in Figure 5d.

\section{Discussions and Conclusions}

\subsection{Importance of Grain Size Gradation}

Grain size gradation is very important to geotechnical engineering. It is an indicator of additional engineering properties such as compressibility, shear strength, and hydraulic conductivity. In a construction design, the gradation of grain size often controls the design and ground water drainage of the site. For example, a poorly graded particle will have better drainage than a well graded particle because there are more void spaces in a poorly graded particle. When a fill material is being selected for a project such as a highway, embankment or earthen dam, the gradation of soil particle is considered. A well graded particle is able to be compacted more than a poorly graded particle of soil [14]. An experimental study reveals that the following criteria must be met for a sand to be classified as well graded, such as- $\mathrm{C}_{\mathrm{u}} \geq 6$. The present analysis met the criteria, like- $C_{u}$ is 9.88 . Therefore, the Maddhapara granite dust is classified as well graded sand or SW that can enhance high compressibility and shear strength.

\subsection{Compressive Strength Values Associated with Different Curing Periods}

It is apparent from our test results that the strength values associated with the curing period of 7 days are quite different from that of the curing periods of 14 and 28 days. The strength values of 14 and 28 days curing periods are almost similar with an increasing trend until grade M15. For the case of 14 days curing period, the M20 grade shows a lower strength value than M15. However, the M25 grade shows a higher strength value exceeding even M15. It is assumed that the difference in strength values for curing period of 7 days from 14 and 28 days could be related to some experimental grounds. For example- (i) the mixing of different materials could have been a problem, and (ii) the reading of strength values from the dial or the tamping of mixtures could also cause another problem. These problems could be resolved with more careful approach of the experiment and test procedures. Although the M25 grade shows the highest strength value, the M15 grade is also a good option because of its high strength and moderate amount of cement with granite dust ratio.
After a long-term laboratory experimental research results, as mentioned above, we can come into the following conclusions-

- From the grain size distribution curve data (Figure 4) associated with $\mathrm{C}_{\mathrm{u}}$ and $\mathrm{C}_{\mathrm{c}}$ values, it is well-known that the Maddhapara granite dust is well graded and can be classified as well graded sand or SW that can bear high compressibility and shear strength.

- The compressive strength test results with different grades of concrete cube reveal that the use of granite dust of the Maddhapara Granite Mine will yield an effective result with very high values of compressive strength.

- The M15 grade is highly recommended. It would be cost effective because of its relatively high strength value associated with moderate amount of cement and granite dust ratio.

\subsection{Techno-economic Feasible Aspects of the Maddhapara Granite Dust}

It is reasonable to mention that granite dust in the Maddhapara Mine is considered as waste material and no economically viable option has been considered yet. Literatures review highlights that the particles of granite dust are irregular, angular and porous and have rough and crystalline surface texture. The particle size is nearly similar to fine sand. Granite dust particles have high interlocking characteristics [4]. Crushed granite dust can be used in concrete aggregate to replace natural sand in varying percentages, where compressive strength value increased with increase in crushed granite powder content [16]. Scholarly research works [4] also reveal that the granite dust can be utilised in various construction applications and building materials. At present, granite dust is used worldwide for the following applications:

- As a filler material for roads and embankments.

- For manufacturing bricks.

- Manufacturing of thermo-set resin composites.

- Manufacturing of hollow bricks and tiles.

- Soil stabilization.

- Aggregate for concrete manufacturing.

- Granite dust can be used to produce granite dust blended cement, as cement replacement, using 5.0\% granite dust. This content, $5.0 \%$, enhances concrete properties of granite dust modified concrete [17].

- For the case of Maddhapara granite dust, it can be used as an alternative material for construction aggregates rather than that of river sand.

From the technical and economic points of view, it is rational to conclude that if the granite dust of the Maddhapara Mine can be used in various purposes as mentioned above, it would not only save large amount of construction cost, but also would provide an economic window of the mine economic aspects. 


\section{References}

[1] Hudson, B. P., "Manufactured Sand for concrete," The Indian concrete Journal, May 1997, pp. 237-240.

[2] Srinivasa, C. H, Venkatesh., 2015. Optimization of Granite Powder used as Partial Replacement to Cement in the Design of Ready Mix Concrete of M20 Grade using IS10262: 2009. International Journal of Engineering Research \& Technology (IJERT) 4 (1), 104-111.

[3] Elmoaty, A. E. M. A., 2013. Mechanical properties and corrosion resistance of concrete modified with granite dust. Construction and Building Materials 47, 743-752.

[4] Singh, S., Nagar, R., Agrawal, V., 2016. A review on Properties of Sustainable Concrete using granite dust as replacement for river sand. Journal of Cleaner Production 126, 74-87.

[5] Popovics, S., 1979. Concrete-Making Materials, p. 208-210, Hemisphere Pub. Corp., Washington, 1979.

[6] Bonavetti, V. L., and Irassar, E. F., 1994. The effect of stone dust content in sand. Cement and Concrete Research. 24 (3), 580-590.

[7] Kalchef, I. V., 1977. Portland cement concrete with stone dust, Special Engineering Report, 20 p., National Crushed Stone Association, Washington (1977).

[8] Malhorta, V. M. and Carette, G. G. 1985. ACI Journal, 82 (3), 363-371.

[9] Ahmed, A. E. and El-Kourd, A. A., 1989. ACI Materials Journal, 86 (4), 417-424.
[10] Hamza, Aizboon, K. K., 2013. Effect of using granite slurry in concrete", Construction and building materials 10, 1014-1020.

[11] Prakash Rao, D. S. and Giridhar Kumar, V, (2004), "Investigation on concrete with stone crusher dust as fine aggregate", The Indian Concrete Journal, vol 78, No 7, pp. 45-50.

[12] Bhikshma, V., Kishore, R., Raju, N. H. M., 2010. "Flexural behavior of high strength stone dust concrete. "Challenges, Opportunities and Solutions in Structural Engineering and Construction". Taylor \& Francis Group, London, ISBN 978-0415-56809-8, p. 491-494.

[13] Concrete mixes and purposes, Retrieved on $3^{\text {rd }}$ November, 2015. from: http://www.slideshare.net/suryaom/basic-construction-element.

[14] ASTM C109/C109M. "Standard Test Method for Compressive Strength of Hydraulic Cement Mortars (Using 2-in. or [50-mm] Cube Specimens)." (1999).

[15] Holtz, R. and Kovacs, W. (1981), An Introduction to Geotechnical Engineering, Prentice-Hall, Inc. ISBN 0-13-484394-0.

[16] Adigun, E. M. A., 2013. Cost effectiveness of replacing sand with crushed granite fine (CGF) in the mixed design of concrete. IOSR J. Mech. Civ. Eng. (IOSR JMCE), 10 (1) (2013), pp. P01-P06.

[17] Elmoaty, A. E. M. A., 2013. Mechanical properties and corrosion resistance of concrete modified with granite dust. Construction and Building Materials 47, 743-752. 